\title{
The Social Construction of Gender in Traditional Igbo Societies: A Comparative Study of Language used as Socialization in John Munonyes's the Only Son and Flora Nwapa's Efuru
}

\author{
Cletus Ikechukwu Anah Ph.D ${ }^{1 *} \quad$ Mary Chizoma Okere Ph.D ${ }^{2}$ \\ 1.Social Science Unit, Directorate of General Studies, Federal University of Technology, Owerri \\ 2.Use of English Unit, Directorate of General Studies, Federal University of Technology, Owerri
}

\begin{abstract}
The Social Construction of gender is hinged on the belief that gender is culturally and psychologically produced. Culture is defined as the totality of man's acquisition as a member of society. It includes all behavioural traits, attitudes, values, beliefs, skills as well as the manufacture and use of material items in a given human society. This is contrary to the widely held view that biological differences are responsible for the distinctions in the behaviour of men and women, including the roles they play and the positions they occupy or do not occupy in society. As an integral component of the social construction of gender, socialisation inculcates in members of the society, acceptable cultural traits while moulding their individual personality (psychology). Since socialisation is a process that begins at birth and ends at death, both young and old members of society are involved. Through this process of socialisation, the culturally acceptable behaviour, values, beliefs and skills for males and females are prescribed, encouraged, reinforced and transmitted from one generation to another. On the other hand, those behavioural patterns, values, belief systems and skills deemed unacceptable by the society are proscribed, discouraged and sanctioned, thereby accentuating the distinctions between masculinity and feminity; highlighting gender as a social rather than biological phenomenon. This paper is a comparison of language used as socialisation in John Munonye's The Only Son and Flora Nwapa's Efuru to illustrate the social construction of gender among the Igbo of South-Eastern Nigeria. The methods or theoretical frameworks employed in this study are content analysis which provides valuable historical and cultural insights over time, through the analysis of the above stated texts and social constructionism, a sociological theory of knowledge which postulates that human development is socially situated and knowledge is constructed through integration.
\end{abstract}

Keywords: Gender, Language, Society, Culture and Socialisation.

DOI: $10.7176 /$ RHSS/9-10-11

Publication date:May $31^{\text {st }} 2019$

\section{Introduction}

This paper examines the network of relationships, cultural practices and aspects of the socialisation process that engender the construction of gender among the Igbo of South-East Nigeria. Whereas John Munonye's The Only Son and Flora Nwapa's Efuru depict traditional Igbo Cultural practices and attendant social network of relationships, this study compares language use in the two narratives to illustrate the social construction of gender. This study is necessitated by the widely held albeit contested view that biological differences between men and women are responsible for gender roles and gender inequality among the Igbo and indeed other known human societies. This view has led to the acceptance of relationships and cultural practices that impose dehumanising roles on women. In some cases, even non-scientific sources as religion are used to justify subjugate positions to particular gender. A typical example is Christian religion where the Bible (Genesis 3:16 King James Version) states that as a punitive measure to Eve, God stated that the woman's desire shall be to her husband and that the husband shall rule over her. This interpretation of the Bible has been used as justification for gender roles and attendant gender inequality.

The objectives of this study therefore include highlighting the socio-cultural, psychological, economic and political motivations and circumstances that initiate and perpetuate gender discrimination, including the prescription and proscription of gender roles. Attention will also be drawn to the fact that most of the purposes served by the discriminatory prescription and proscription of gender roles and the gender inequality that emanate there from have been overtaken by events in present day industrial societies. This is aimed at projecting a clearer elucidation and demystification of the concept 'gender'. It will also assist policy makers in gender mainstreaming of socio-cultural, political and economic issues.

The Igbo of South East Nigeria are predominantly patrilineal. However, there are some exceptions where descent is traced and inheritance follows the female line. These include Afikpo, Nkporo, Ohafia, Abiam and Arochukwu. Egwu (2004) posits that though both the maternal and paternal lineages are important in these communities, the maternal relationships are the most significant culturally. Among the Igbo as in most patrilineal societies, patriarchy, that is, the kinship system in which men dominate the power structure, both economic and political and women are to a large extent excluded operates. This means that political and economic positions 
such as head of family, village or clan are dominated by men. Also land which is the essential means of production in agrarian societies is owned by men. Women are not allowed to own land, not even by inheritance. In addition, the relevant decision making bodies such as the council of Elders or the Eze/Igwe in council are dominated by men.

This patriarchal kinship system regenerates and sustains itself through socialisation but especially language use. For instance, among the Igbo, a popular adage asserts that 'Di nwanyi bu chi ya' meaning that a woman's husband is her god. The male partner in a marriage is thus elevated to the position of a god, making the relationship invariably unequal. A similar Igbo adage has it that 'Ugwu nwanyi bu di ya' literally, this means that a woman without a husband has no honour. It is not uncommon to hear parents, even mothers exhort their male children to 'walk or talk like a man' while the girl child is on the other hand admonished to sit or eat like a woman. The Igbo society therefore employs language use in the construction of gender. The importance of 'language use' as a relational, contextualized account of the evolving self is stressed by Stetsenko and Arievitch (1997) as cited by Mckinley (2015:7) thus:

Language use is taken as a root metaphor for all human

action, and conversation, dialogue, as the root model for the

analysis of all mental processes.

This view is in line with the Sapir-Whorf hypothesis of linguistic relativity. This hypothesis argues that language is much more than a medium for voicing ideas. Language also shapes ideas. In addition, language initiates action and directs the activities of the individual. Thus, language to a large extent shapes the individual's perception of reality (Scott and Marshall 2005).

In the social network of relationships within a given society, status is one of the most important social structures. Status refers to the level of prestige or social honour accorded an individual. It is therefore instructive to this study that as early as the 1920s when formal education but especially higher education was a status symbol, Igbo communities mobilised funds to send their sons to universities in Europe and America to the exclusion of their daughters. Thus, the status of men has remained above that of women among the Igbo. Marriage among the Igbo is not consumed as a union of two equal partners. The woman is subject to the man. Thus the roles and positions of the wife and mother are subordinate to the roles and positions of the husband and father. In the same vein, the male child is preferred to his female counterpart for no practically justifiable reason. It is against this background that this study compares John Munonye's The Only Son and Flora Nwapa's Efuru as narratives that illustrate the social rather than biological origin and sustenance of gender among the Igbo of South East Nigeria.

\section{Literature Review}

\section{The Social Construction of Gender}

Social Construction is a sociological theory that emphasises that social life or social reality that is, what we comprehend or perceive as reality is socially created. Though the idea of constructionism was initially muted by the Chicago Sociologists, phenomenologists such as Alfred Schutz, (1899-1959) the Austrian philosopher and social phenomenologists, it was made popular by Peter Berger and Thomas Luckman's (1966) publication of "the Social Construction of Reality". Social Construction is therefore, the theoretical knowledge that the world is what the people within a given society make of it. Social worlds are therefore "interpretive nets woven by individual groups" (Scott and Marshall 2005:607) Social construction goes beyond the idea of accepting social phenomena as naturally given. The theory therefore questions what human societies define as reality. Social construction is therefore deemed appropriate as a tool to interrogate the social phenomena or reality "gender" among the Igbo of South East Nigeria.

In psycology, there is a related theory known as social constructivism. Though social constructivism is often associated with the work of Jean Piaget (1896-1980) Swiss child development psychologist, it was developed by Lev Vygotsy who rejected Piaget's assumption that learning can be separated from its social context. Fundamental to social constructivism is the recognition that learning or knowledge does not occur in isolation. Learning or knowledge occurs through interaction between people and the environment within which the interaction takes place. As Mckinley (2015:6) puts it,

Constructivist learning has significant implications for the

construction of cultural identity, in that, for adult learners with

many years of experience and accumulated schemata, new

information must be connected to neurological structures already

in existence. Cultural identity building is an on-going process

that is affected by various social, cultural and historical factors.

Gomez-Estern, et al (2010) as cited by Mckinley (2015:6) concur with this view by stating that "cultural identity is not an immutable "essence" placed in the hearth of our mind, but a malleable process that is constructed in relation to the social settings in which people participate". 
Social constructionism and social constructivism are used interchangeably in this study as a result of the similarity in the focus and meaning of these theories. To fully comprehend the essence of the social construction of gender a distinction has to be made between sex and gender. While sex refers to the biological state of being either male or female, gender on the other hand is not biological. Rather, the concept 'gender' draws attention to the socially, psychologically and ideologically created distinction in the roles, social-economic and political positions prescribed for different sexes (male/female) in a given society. Gender therefore accentuates the structural relationships of super ordination and subjugation that exists between men and women in society. These relationships cannot be said to be biological. The distinction between sex and gender despite many years of interchangeable usage of the two was made by Stoller (1968) as cited by Haralambos, Holborn, Chapman and Moore (2013:98).

Gender is a term that has psychological and cultural connotations;

if the proper terms for sex are "male" and "female", the corresponding terms for gender are "masculine" and "feminine".

These later, might be quite independent of (biological) sex.

It is in this vein that Oakley (1974) as cited by Hralambos et al (2013) posits that gender roles are not biologically produced. She is of the view that it is not the biological differences between men and women that lead to the roles, political or economic positions they occupy in society. Rather, it is the culture of a particular society that exerts most influence in the creation, proscription and prescription of masculine and feminine behaviour for both male and female. Kessler and Mckenna (1978) as cited by Haralambos et al (2013) influenced to a large extent by their ethno methodology background project this view beyond gender roles. They opine that gender attribution, the ability to recognise an individual as either male or female is socially produced in the same way as gender roles.

However, other social scientists have attributed the differences in social roles and attendant inequality between men and women to biology. Parsons (1955) representing the functionalist viewpoint claim that the main explanation for the allocation of roles on the basis of sex lies in the fact that the bearing and nursing of babies establishes a strong relationship between the mother and child. This, according to the functionalist perspective positions the female sex in an advantageous position for the socialisation of the child and the stabilisation of adult personalities and the society writ large. This is in tandem with functionalism's quest for stability and equilibrium in society. The functionalist theory views society as a complex system whose parts 'function' to promote the well-being and stability of not only the components but society as a whole. The constituent elements are social institutions, the traditions and customs within a given society. Gender inequality therefore exists because particular components or segments of society are best suited for specific responsibilities; a sort of division of labour that enhances resource use and promotes efficiency. For instance, women take care of the home while men provide for the family. These roles are seen as complementary and contribute to the stability of the society (Reece McGee et al 1980).

It is pertinent to point out here, that in present day industrial societies, many women provide for the family while their husbands take care of the home. Also, there are large members of single parent homes where this division of labour along gender lines do not operate. For radical feminists, what the functionalist perceive as complementary roles are oppressive positioning of men and women, the latter subordinate to the former. Following the success attained in the universal adult suffrage movements of the $19^{\text {th }}$ and $20^{\text {th }}$ century, women liberation movements emerged in the 1960s and 1970s to agitate for equality between male and female. Feminist theory emerged from these movements and has spread to various academic disciplines as well as having such subdivisions as radical feminism, Marxist, socialist feminism, liberal feminism, black feminism and post-modern feminism. (Haralambos et al (ed) 2013:104). Despite these divisions, feminism in general, questions, measures and faults the usually accepted assumptions regarding female and male attributes and attendant relationship between the two. Mackay (2015) identifies Radical Feminism, using four criteria. First, radical feminists see society as patriarchal, which means society is dominated and ruled by men thereby exploiting women. Radical feminists are thereby committed to eliminating patriarchy. The second criterion which is related to the first is the use of an organising method that excludes men completely. Thirdly radical feminism highlights all forms of male violence against women and focus on these as the benchmark of oppressions against women. Finally, radical feminism includes the institutions of prostitution and pornography in their analysis of violence against women. These distinctions notwithstanding, feminism in general has drawn attention to the suppression of women by men.

\section{Synopsis of the Two Novels}

Efuru: The story revolves around Efuru, the novel's eponymous character. Efuru is a beautiful and kind-hearted woman. These qualities endear her to everyone that comes in contact with her. Following her consultation of a 'dibia' in a quest to unravel the meaning of her incessant dreams of the 'woman of the lake', the sage reveals that the river goddess (Uhamiri) has chosen her to be one of her worshippers. Consequently, she cannot marry or 
have children successfully. She must remain alone. The goddess does not give her worshippers children and she has none. She gives beauty and wealth only. The restrictions placed on Efuru as a devotee of Uhamiri are clearly enacted in the story as her first and second marriages fail. She returns to her father's house and devotes her life serving the river goddess.

The Only Son: Set in two traditional Igbo communities- Umudiobia and Nade, The Only Son (henceforth TOS) centres on Chiaku a young widow and Nnanna her only son. Nnanna is not just an only son, but an only child of his mother hence; Chiaku's whole life is centred on him. Due to a misunderstanding between Chiaku and Amanze, her late husband's brother, she flees Umudiobia with her son and sojourns in Nade among her people. Chiaku rejects every advice for remarriage because she cannot think of leaving Nnanna to fend for himself. She is devoted to bringing her son up in the traditions of their people in the hope that he will one day marry and continue her late husband's lineage. Unfortunately this is never to be. Her whole world crumbles and her dreams shatter when Nnanna joins the "evil gathering". At last he goes to Ossa to work for Reverend Father Smith and to receive Western education.

\section{Findings and Discussion}

This study textually examines how John Munonye and Flora Nwapa have in their novels TOS and Efuru respectively represented male and female genders through language use (verbal appellations). Striking features are brought out. Variations and similarities are highlighted and discussed.

\subsection{Representation of Man in TOS and Efuru}

The use of verbal appellations in gender socialisation in the texts under study is less frequent with male than with female. Analysis of the portrayal of male gender in the texts reveals little or no difference between Munonye and Nwapa.

The authors portrayed man as a brave and powerful figure. In TOS there are noun phrases like 'heart of the mother', 'many in one', 'mother's hero'. These are used in apposition to Nnanna after he rescued his mother (Chiaku) from Amanze and his wives by shooting an arrow into the leg of one of Amanze's wives.

Nwapa illustrates this through the description of Nwashike Ogene. She writes:

... Nwashike Ogene, the mighty man of valour. Ogene who single handed

fought against the Aros when they came to molest us (Nwapa, p.11).

Again, both authors share the idea that man is strong and superior. This is amply demonstrated in TOS. In the conversation between Chiaku and Nnanna, Munonye shows man's superiority over woman.

You deposited the lumps inside your throat all at once, she (Chiaku) said in reproval. Now you pant like a lizard that has just dropped from a high wall.

I ate like a man, he (Nnanna) answered her with an air of superiority.

See how you eat your own like a snail crawling (p. 22).

Through Idimogu, Munonye's portrayal of man as strong and superior is exemplified. In the narrative, both Idimogu and Chiaku had lost their sons to the new faith. Unlike Chiaku, he did not show his grief because according to him:

a man should eat his sorrow in his heart; if not I should

have been in tears (p. 52).

Even later in the text when Chiaku observed that he does not look sad despite his misfortune he remarked:

A man's heart eats many sad things. I am a man after all (p. 93).

Eneberi in Efuru further demonstrated man's superiority when he said to Efuru:

That we are in the same age-group does not mean that we

are the same age. Besides, I am a man and you cannot break

kola in my presence (p. 85).

It is true that in Igbo culture a woman does not break kola or shown kola before it is broken and a male irrespective of his age can break kola. But, whichever way it is considered, it seems that the prevailing values, norms and beliefs and practices perform the ideological function of maintaining the present pitiable predicament of women in traditional Igbo societies. In other words, the belief that men are superior to women in African societies generally is strengthened by the inherent cultural myth and societal canons.

From the foregoing it is evident that the portrayal of man by the authors is a reflection of the traditional position accorded men in patriarchal Igbo society. The overall portrayal of man is as a strong, powerful, superior and authoritative creature.

\subsection{Representation of Woman in TOS and Efuru}

All through history, gender apartheid has given rise to stereotypic imaging of women which not only misrepresent them but also damage them (Bamgbose, 2012). When representing female gender, the two authors 
John Munonye and Flora Nwapa are alike. A striking depiction of woman in the two novels is as an embodiment of modesty and virtue. This is supported by the use of attributive adjectives 'good' and 'nice' with almost all the female characters in TOS and Efuru. Thus, there are many instances of the following appositive noun phrases 'a good girl', 'a beautiful woman', 'a good child', 'a nice girl', 'a good woman', 'a good daughter', and 'a beautiful daughter'.

Comparatively, Munonye portrays the idea that being good is a condition for a woman's recognition in a patriarchal society even when she is exploited or gets no reward for it. On the other hand, Nwapa shows disapproval of goodness born out of irrationality and passivity when she writes:

Few women would be satisfied with this. But Efuru, good natured as she was, did not even find out what the foolish act was. Since her husband did not steal she was at peace (Efuru, p.210).

Later in the narrative, Efuru regretted her passivity when in the course of narrating to Difu why she opted out of her second marriage she says:

As foolish as I was, I believed him. I did not as much

as press him to tell me the foolish act (p. 219).

In the event presented here, Efuru could not find out the whole truth about her husband's imprisonment at Onicha. As soon as he told her that he did not steal but was imprisoned for his foolishness, her anger and resentment dissipated probably because, she fears being labelled aggressive. In patriarchal societies, both men and women have been conditioned to believe that aggressiveness is an exclusive male trait.

In another vein, both authors have portrayed woman as a weak and helpless being. She is represented as one who should be dependent, silent and submissive. She is, as Ngara (1989) puts it, "an object to be acted upon; a thing who owes a debt and allegiance to men by virtue of her sex". In Efuru, this is illustrated through Efuru when she says:

He is the lord and master, if he wants to marry her I cannot stop him (p.55).

She goes on:

Only a bad woman would like to be married alone

by her husband (p.57).

Nwashike ((Efuru's father) puts it this way:

It is only a bad woman who wants to have a man all to herself (p.63).

In TOS, Andrew asked his wife: "Did you hear that your sex should not preach?"

Amanze's statement provides further illustration. Chiaku had told Amanze some home truths about his illtreatment of Nnanna which did not go down well with him. He questions her audacity this way:

'Dare you talk to me like that? He objected. Do you forget

that you are a woman?" (Munonye 1966:7).

In the above lines Amanze is no doubt asking Chiaku if she has forgotten that women should be silent and submissive to their husbands or any male figurehead. He is asking if she has forgotten that as a woman in a male-dominated society, she is meant to be seen and not heard. Just as Ngara (1989) rightly says, the views of women expressed by male African writers do to some extent correspond with the actual position of women in African society. One can therefore see the reason for Chiaku's failure to realise her dream. Chiaku had refused to remarry after losing her husband at a young age. Her intention was to remain in her late husband's house and raise her only son as a single parent in the hope that he will marry one day and continue the lineage. Unfortunately, all her efforts towards the realisation of this dream became fruitless because Nnanna got converted to Christian religion and never fulfilled all the expectations placed on him by the society. Thus, Chiaku was punished for daring to stray from feminine norms. At the end she is where the society expects her to be - under the care and protection of a man as she remarries.

In another instance Ezedibia refused to attend to Chiaku when she consulted him for solution to her problem. He puts it this way:

... surely, such request as you make should have come from a man.

If you would ask your brother to see me about the matter, I could

arrange to be there before it's too late (Munonye 1966:102).

The foregoing conveys the idea that a woman must depend on a man for survival. She must be under the guidance and protection of a man. Really, this excessive patronage of women has resulted in the denial of their rights in virtually all aspects of life.

However, for Nwapa through the character Efuru, submission is not 'head bowed'. Head bowed as submission according to Utoh-Ojemudia (2011) may be carrying heavy stories of humiliation and bitterness. Through Efuru Nwapa shows that women have freedom of choice. They have the ability to take responsibility for their actions. Having waited for over a year for Adizua's return, she decides to end the marriage. She tells her mother-in-law: 
Mother, I cannot stay any more. A man said that he had wept for the death that killed his friend, but he did not wish that death to kill him. I cannot wait indefinitely for Adizua, you can bear witness that I have tried my best. I am still young and would wish to marry again. It will be unfair both to you and your son if I begin to encourage men who would like to marry me while still in this house (Nwapa 1966:88).

Earlier on Efuru had soliloquized:

... our ancestors forbid that I should wait for a man to drive me out of his house. This is done to women who cannot stand by themselves, women who have no good homes and not to me the daughter of Nwashike Ogene. And besides, my face is not burnt. I am still a beautiful woman (Nwapa p.64).

In the two instances one could see the courage, inner strength and resilience of Efuru. Being a successful business woman, she knows that she can live a fulfilled life without depending on a man. Another depiction of woman in the novels worth mentioning is as a home keeper. In traditional African society, a woman's sacred place of work is the home and her worth is measured by her ability to keep a home. There are evidences of socialisation into this gender role in TOS and Efuru. For instance, in TOS, Chiaku commended Ego for sweeping very well. She visited Ego's mother one early morning and met Ego sweeping the compound. In admiration, she said to Ego "good daughter, you sweep very well." Ego's mother concurred to this and added that she had already been to the stream.

In Efuru, Ajanupu's statement provides another illustration. She tells Ogea:

Bend down properly, you are a girl and will one day marry. Bend down and sweep like a woman (Efuru, p. 9).

Later the same day, Ajanupu had this to say to Efuru:

You are spoiling Ogea. You just leave her to do what she likes.

Remember she is a girl and she will marry one day. If you don't bring

her up well nobody will marry her. . . . a girl of her age should know how to cook everything (p. 44).

In another instance, Amede complained to Omirima about Ogea's inability to wash clothes properly. She says: She washed my wrappers and all of them will have to be washed again because there is still black soap on all of them. How is it that a grown-up girl like that is not able to wash clothes properly? How can she live in a man's house? (p.181).

It is unfortunate that this role is so elevated that a woman who cannot perform household chores is seen as defiling femininity hence; women in traditional African societies are so engrossed in meeting the societal expectations of them that they lag behind in the other spheres of life.

\section{Conclusion}

The representations of male and female genders in the two novels under study are stereotypical. Through the process of verbal appellations, the authors have depicted the social construction of masculinity and femininity thereby representing gender in line with what is and what is not considered acceptable behaviour for men and women in traditional Igbo society.

Although TOS and Efuru differ thematically, there are many similarities in the way the authors represented the male and female characters. A study of the texts has shown that the authors presented their narratives from a strong patriarchal point of view. Man is portrayed as strong, powerful, superior and authoritative. The woman on the other hand is presented as weak, dependent, passive, inferior and irrational. However, while this portrayal is strong in TOS, it is somewhat fluid in Efuru. This can be expected. Nwapa has been described as part of a wave of female African writers whose novels defied the traditional depiction of African women as passive (Perdigao, 2017). To this end, Nwapa explored what Banyiwa-Horne (1986) as cited in Opia (2011) described as alternated possibilities for self-actualisation outside the sexual roles that are open to female characters. In other words, Nwapa tends to create a woman's world in which her female characters exist in their own right and not as mere appendages to a male world. We can, therefore, conclude from our findings that a closer study of the representation of male and female characters would lead to a better understanding and appreciation of John Munonye's TOS and Flora Nwapa's Efuru.

\section{References}

Bamgbose, G. S. (2012), "Modern African poetry and the issues of gender: Nigerian Literary Scene", Research on Humanities and Social Sciences 2(11), 94-105. 
Egwu, U.E. (2004), "Unravelling and Celebrating an Enigmatic Igbo Scholar" Citation of Professor Inya-Agbam Eteng. In Eteng I.A (2004), Onye Ajuru Aju Anaghi Aju Onwe Ya: Ndi Igbo in Post-Civil War Crisis of Disunity. Owerri Ministry of Information and Culture.

Haralambos, M., Holborn, M., Chapmas, S. \& Moore, S. (2013), Sociology: themes and perspectives. London: Harper Collins Publishers Ltd.

Mackay, F. (2015), On Radical Feminism: Theory, Culture and Society. (Online) Available: http://www.theoryculturesociety.org (January 8, 2019)

Mckinley, J. (2015), “Critical Argument and Writer identify: Social Constructivism as a Theoretical Framework for EFL Academic Writing”, Critical Inquiry in Language Studies 12(3), 184-207.

Munonye, J. (1966). The Only Son. London: Heinemann

Ngara, E. (1989), "The portrayal of women in African literature", Kunapipi 11(3). (Online) Available: htpp://ro.uow.edu.au/kunapipi/vol11/iss3/10 (February23, 2019)

Nwapa, F. (1966). Efuru. London: Heinemann

Opia, N. I. (2012), "Liberal feminism as a re-invention of femality in the African novel: a hermeneutic approach to Chimamanda's Half of a Yellow Sun”, In P. A. Anyanwu and I. Obuasi (eds.) Issues in language and human development. Nigeria: San Press Ltd, 477-486

Perdigao, Y. P. (2017), "Flora Nwapa and the African woman's struggle to identify as feminist", (Online) Available: nzigaeffect.com/flora-nwapa-african-woman-feminism/ (February 29, 2019)

Scott, J \& Marshal, G. (eds.) (2005), A dictionary of Sociology. Oxford University Press

Utoh-Ojemudia, C. C. (2011), "Addressing gender negation for sustainable development: the portrayal of women in creative works", In A.B.C. Chiegboka, T. C. Utoh-Ezeajugh \& M. S. Ogene eds. The humanities and sustainable development. Nigeria: Rex Charles \& Patrick Ltd, Chapter 14

\section{Biography}

First Author: Dr. Cletus Ikechukwu Anah is a Senior Lecturer in the Directorate of General Studies, Federal University of Technology, Owerri. His first degree, Bsc (Hons) in Sociology and Anthropology was obtained from the University of Nigeria, Nsukka. The Masters (Msc) and Doctorate (Ph.D) in Sociology were obtained from the University of Port Harcourt. Dr. Cletus Ikechukwu Anah's research interests include development studies, trade union and working class studies, and gender studies. Dr. Anah is married with children.

Second Author: Mary C. Okere is a Lecturer 1 in the Language Unit of the Directorate of General Studies, Federal University of Technology, Owerri. She holds a Ph.D in Language Education and two Master's degrees in Language Arts and Language Education all from the University of Ibadan. Her major areas of research interest include: language teaching, gender issues, general linguistics among others. 